\title{
Chapter 9 \\ The Programme for the Endorsement of Forest Certification (PEFC) and Its \\ Contribution to Sustainable Forest \\ Management in Indonesia
}

\author{
Pratiwi Kartika, Hariyadi, and Cerdikwan
}

\section{Introduction}

Indonesia has an extensive tropical forest, which accounts for almost half of its land. This signifies not only plentiful resources but also numerous problems such as forest fires, deforestation and illegal logging. Although the government has put in place several regulations to address them, these problems persist. Effort was also taken at the international level, with the international community offering an internationallyrecognized, private certification to companies practicing sustainable forest management (SFM). Since the effort is initiated by a private agent, this certification is voluntary. The International Trade Centre (ITC, 2012) reports that there are 17 types of voluntary standards that have been implemented in many countries with many types of products certified. In forest management, so far, there have been two internationally-recognized voluntary sustainability standards (VSS) which can be obtained by any forest concession holder in Indonesia-Forest Stewardship Council (FSC) and Programme for the Endorsement of Forest Certification (PEFC).

VSS, or private voluntary standards (PVS), emerged at a time when inter-state negotiations on collective action for social and environmental concerns had reached a deadlock. Private actors, namely multinational corporations (MNCs) and nongovernmental organizations (NGOs) came up with some agreement over good social and environmental practices, known as sustainability standards (Djama, 2011). In many cases, VSS are seen as a more effective way to enforce sustainable practices

\footnotetext{
P. Kartika

Independent Consultant, Amsterdam, The Netherlands

Hariyadi

Research Centre, Secretariat General of the House of Representatives, Jakarta, Indonesia

Cerdikwan $(\bowtie)$

Ministry of National Development Planning/National Development Planning Agency (Bappenas), Jakarta, Indonesia

e-mail: cerdikwan@gmail.com
} 
amongst the producers than government regulations (Hagen \& Alvarez, 2011; Djama, 2011). Thus, VSS are deemed to weaken governments' role. In terms of actual practice, private and public standards are often seen as duplicating, but sometimes, complementing each other (Hagen \& Alvarez, 2011). Multiple standards may be harmful for producers due to the larger compliance cost (Hagen \& Alvarez, 2011; Ruslandi, Klassen, Romero, \& Putz, 2014).

This chapter investigates whether PEFC complements the mandatory standard as well as the FSC, and whether it plays an important role for sustainability practices in the Indonesian forest industry. We focus on PEFC since little attention has so far been given to this standard. FSC, which was introduced in Indonesia in the 1990s, has received much more attention (Ruslandi et al., 2014; Romero et al., 2015). This chapter further aims to analyse whether PEFC is likely to be widely applied in Indonesia and thus help address the forest management problems in the country. This research is based on interviews conducted with a forestry research institution, an Indonesian association of forest concession holders-Indonesian Forestry Certification Cooperation (IFCC) (through which PEFC was introduced in Indonesia) and a certification body. In addition, this research is based on an analysis of documents of PEFC, FSC and of the public mandatory standard, Sustainable Forest Production Management (PHPL).

This chapter proceeds as follows. Section 2 describes forest management problems in Indonesia and a series of government regulations addressing these problems. Section 3 reviews a number of standards existing in the country both in the past and in the present, and discusses whether the PEFC fills in for what was lacking in the PHPL, SVLK (Timber Legality Assurance System), and FSC. Section 4 explores several features indicating PEFC's acceptability in Indonesia and its role in contributing to SFM in the country. Section 5 provides a conclusion on whether PEFC is likely to be widely applied in Indonesia to help remedy the unsustainable practices in Indonesian forestry.

\section{Forest Management in Indonesia}

Indonesia has an extraordinary biodiversity and huge size of tropical forest. In accordance with Act No. 41/1999 on Forestry, forest area includes conservation forest, protection forest and production forest. Referring to the Forestry Statistics of Indonesia 2013, the total forest including inland water, and coastal and marine ecosystems accounted for 129.43 million hectares (MOEF, 2014) while later statistics (2017) placed the figure at 125.92 million hectares (MOEF 2018). However, Indonesia has been facing daunting challenges to protect and manage its forest resources due to its high rates of deforestation, illegal logging, social frictions over forest rights between the government and local communities, etc. The underlying sources of many, if not most, of these challenges rest on the confusion and disagreement over who should control or own Indonesia's forests (Contreras \& Fay, 2005). Research on land-use 
and remote sensing data reveals that significant forest areas are in fact communityplanted agro-forests, agricultural lands and grasslands. The government, however, views them as natural forests or lands to be reforested for timber production, and this often results in conflicts (Contreras \& Fay, 2005). Other serious challenges include forest fires and deforestation. The deforestation rate inside and outside forest areas in Indonesia remains high; for the period of 2011-12, it reached a figure of 613,480 ha per year (MOEF, 2014). Through tougher efforts, the government has succeeded in reducing the deforestation rate to 480,010 ha per year for the period of 2016-2017 (MOEF 2018).

To respond to these challenges, the government has in fact launched several tough policies and efforts. Reinforcing the existing legal framework, the government passed the so-called lex specialis Act No. 18/2013 on the Deterring and Combating of Forest Deteriorating Actions. Partly, these policies aim at reinforcing previous progressive initiatives relating to the reduction of carbon emissions from the forest sector that was launched in October 2009 wherein Indonesia committed to reducing national emissions by $26 \%$, or by as much as $41 \%$ against business-as-usual by 2020 with international support (G-20 Leaders Summit, September 2009). Apart from designing related policies to achieve this target, Indonesia embarked on two consecutive twoyear moratoriums on forests and peat lands concessions. In 2011, the government issued a presidential decree on the national action plan to reduce GHG emissions. With the new administration, through midterm national development planning 20152019, the government embarked on a more ambitious policy route to upgrade SFM and conservation measures (Appendix I, Presidential Decree No. 2/2015). For the post 2020 period, the government envisions a progression beyond its existing commitment to emission reductions. Based on the country's emissions level assessment, the government has set an unconditional reduction target of $29 \%$ and a conditional reduction target of up to $41 \%$ of the business-as-usual scenario by 2030 (UNFCCC, 2016).

Forest management and conservation measures and policies have evolved dynamically over time and they have been determined by both societal values as well as socio-economic and political conditions. Making them work effectively is a serious challenge (Maryudi, 2015). In order to promote SFM in the light of the growing scepticism about the effectiveness of governmental policies and initiatives, and the perceived failure of a global intergovernmental mechanism to stop deforestation and forest degradation, voluntary certification schemes were seen as a viable alternative to sustain nationally existing mandatory policies and regulations (Maryudi, 2015; Van Bueren, 2010).

\section{Forest-Related Standards in Indonesia}

Forest certification is not new to Indonesia. The country has engaged with forest certification since 1990. Indonesia has its own national forest certification system, called Indonesia Ecolabelling Institute (LEI_Lembaga Ekolabel Indonesia), which was 
introduced in 1997. In 2000, this institute signed a Joint Certification Program (JCP) with the FSC (Muhtaman \& Prasetyo, 2006). FSC certification, as an international certification system, has also been available in Indonesia for some years. In 2009, the government started the mandatory certification programmes-PHPL (Sustainable Production Forest Management) and SVLK (Timber Legality Assurance Scheme).

PHPL was endorsed through several government regulations, i.e. Govt. Reg. No. 6/2007 junto No. 3/2008 on Forest Governance, the Establishment of Forest Management Plans and Forest Utilization, and MOEF Reg. No. 38/Menhut-II/2009 junto Permenhut P.68/Menhut-II/2011, junto Permenhut P.45/Menhut-II/2012, junto Permenhut P.42/Menhut-II/2013 on Standards and Guidelines for the Assessment of the Sustainability Performance of Production Forest Management and for Timber Legality Assurance for Concession Holders or People's Forests (Nurtjahjawilasa, Duryat, Yasman, Septiani, \& Lasmini, 2013). This programme aims to enforce the existing laws in order to ensure that forest management is subject to sustainability principles. Since this programme is a mandatory government instrument, it does not relate to the technical issue of trade of forest products and is not targeted at fulfilling market demands. The programme sets five basic criteria relating to the following aspects: (1) legality and security of forest resources; (2) product sustainability; (3) conservation, ecology and environment; (4) economic benefits and (5) institutions (Nurtjahjawilasa et al., 2013). To measure the degree to which PHPL is performed by a forest management unit, there is measurement guidance and standardization. This standardization and guidance are then used as instruments for the certification process by an independent assessor.

SVLK is a mandatory tracking system, effective since 2009 , which was developed by involving multistakeholders to ensure the legality of sources from which timber is being traded in Indonesia. The system seeks to improve forest management and to maintain the credibility and legality of Indonesian timber. It was eventually integrated into the PHPL programme. Pursuant to the Ministry of Trade's Regulation No. 64 in 2012, there are 40 timber-based products obliged to obtain the SVLK certificate. The SVLK audit is performed by a certification body which has been certified by the National Accreditation Committee (KAN) to be a Timber Legality Verification Body (LV-LK) in line with MOEF's Decree. This policy reflects the government's commitment to fight illegal logging and illegal timber trading and to fulfil international market demand for certified legal timber-in particular from the European Union (EU), USA, Japan and Australia. This system can be seen as a "national incentive" to respond to the increasing demand for timber legality certification schemes from abroad, such as FSC and PEFC (Ministry of Environment and Forestry/MOEF, 2016). By the end of 2016, about 24 million hectares of forest and 2843 forest-based industries were SVLK certified (The Jakarta Post, 2016).

Obtaining certification is not always easy, and there are several barriers that prevent or discourage voluntary certification in particular. Bartley (2010) and Ruslandi et al. (2014), in their study of FSC certification in Indonesia, point to a lack of market incentive as one of the barriers. The EU, as the most green-conscious market, is apparently not Indonesia's largest export destination for timber and timber products. Another barrier is the high cost of achieving the standards required by 
Table 1 Forest management components and their references to FSC and PEFC principles

\begin{tabular}{l|l|l}
\hline Forest management components used in this study & FSC principles & PEFC principles \\
\hline $\begin{array}{l}\text { Compliance with laws and satisfaction of financial } \\
\text { obligations }\end{array}$ & 1 & 1 \\
\hline Implementation of reduced-impact logging & $5,6,7,8$ & $2,3,4,6$ \\
\hline $\begin{array}{l}\text { Social impact assessment and community development } \\
\text { programs }\end{array}$ & 3,4 & 9,10 \\
\hline Environmental management and monitoring plans & 6,8 & $2,6,3,4$ \\
\hline Biodiversity conservation & 9 & 7 \\
\hline Worker rights, health and safety & 4 & 11 \\
\hline Yield sustainability and silviculture & $7,8,10$ & $2,3,5,8$ \\
\hline
\end{tabular}

Source Columns 1 and 2 from Ruslandi et al. (2014); Column 3 authors' elaboration

FSC. To obtain the certificate, a concession has to pay audit fees, make infrastructure improvements and forgo the profits from unsustainable practices. From the five concession areas that Ruslandi et al. (2014) focus on in their research, the concessions needed time as long as from 3 to 10 years to get the FSC certificate. Another international voluntary certificate introduced in Indonesia is PEFC. The Indonesia Forest Certification Cooperation (IFCC), which introduced PEFC in Indonesia, was established in 2011, and the standards of PEFC Indonesia were endorsed in 2014.

\section{Comparison of PEFC, FSC and Government Regulations}

To get an idea of whether PEFC, FSC and government regulations are substitutable or complementary, the three standards are compared across seven forest management components. Each component is matched to its reference in PEFC and FSC principles, respectively (Table 1).

Referring to the seven forest management components above, Table 2 comparatively displays governmental regulations, FSC and PEFC requirements. Features of the requirements of the two voluntary certification schemes will be elaborated subsequently.

With regard to compliance with regulations and satisfaction of financial obligations, both PEFC and FSC strengthen government regulations. However, PEFC explicitly mentions that concessions have to comply with the SVLK-the public mandatory standard. This implies that in this regard, PEFC does not want to be contradictory to government regulations. In addition, PEFC has some additional requirements such as to identify an adequate infrastructure for delivery of goods and protection of ecosystem, and to carry out R\&D activities. However, in general, PEFC has many similarities with FSC, e.g. concessions have to abide with national legislations, pay all of the financial obligations to the government, and state explicitly their commitment to SFM.

As for the implementation of reduced-impact logging $(R I L)$, the PEFC requirement is similar to that of FSC as it includes criteria, e.g. on tree felling, bucking and log yarding, as well as on soil and water protection functions. Since the implementation 
Table 2 Comparing governmental regulations and voluntary certification schemes' requirements

\begin{tabular}{|c|c|c|c|}
\hline $\begin{array}{l}\text { Forest management } \\
\text { components }\end{array}$ & Government regulations & FSC requirements & PEFC requirements \\
\hline $\begin{array}{l}\text { Compliance with } \\
\text { regulations and satisfaction } \\
\text { of financial obligations }\end{array}$ & $\begin{array}{l}\text { Comply with TPTI rules; } \\
\text { Comply with labour and } \\
\text { environmental laws; } \\
\text { Pay reforestation fees (DR) } \\
\text { and forest royalties } \\
\text { (PSDH); } \\
\text { Compensate local } \\
\text { communities (about } \\
\text { USD } 1 / \mathrm{m}^{3} \text { in Kalimantan } \\
\text { and USD } 10 / \mathrm{m}^{3} \text { in Papua); } \\
\text { Issuance of annual cutting } \\
\text { permits and license } \\
\text { renewals conditional on } \\
\text { legal compliance, as } \\
\text { determined by external } \\
\text { auditors (SVLK) }\end{array}$ & $\begin{array}{l}\text { In addition to complying } \\
\text { with national and local } \\
\text { laws, concession should } \\
\text { recognize and respect local } \\
\text { community rules; negotiate } \\
\text { and make an agreement on } \\
\text { the compensation fee } \\
\text { for the communities; deal } \\
\text { with FSC rules that } \\
\text { sometimes contradict } \\
\text { national regulations (e.g. } \\
\text { SILIN rules require } \\
\text { unsustainable logging } \\
\text { intensities); provide } \\
\text { evidence of balanced } \\
\text { attention to social, } \\
\text { ecological, and production } \\
\text { issues and provide } \\
\text { documentation for forest } \\
\text { delineation and resolve any } \\
\text { related conflicts }\end{array}$ & $\begin{array}{l}\text { Similar to FSC } \\
\text { requirements, with } \\
\text { additional requirement } \\
\text { that concessions explicitly } \\
\text { comply with SVLK, to } \\
\text { identify an adequate } \\
\text { infrastructure for delivery } \\
\text { of goods and protection of } \\
\text { ecosystem, and to carry } \\
\text { out R\&D activities }\end{array}$ \\
\hline $\begin{array}{l}\text { Implement reduced-impact } \\
\text { logging (RIL) }\end{array}$ & $\begin{array}{l}\text { RIL is the MOEF's } \\
\text { principal proxy for SFM in } \\
\text { their mandatory forest } \\
\text { certification program } \\
\text { (PHPL); } \\
\text { Prepare tree position maps } \\
\text { and plan logging roads, but } \\
\text { these are only } \\
\text { administrative } \\
\text { requirements }\end{array}$ & $\begin{array}{l}\text { Pre-harvest timber } \\
\text { inventories and contour } \\
\text { mapping; } \\
\text { Harvest plans to reflect } \\
\text { established standards for } \\
\text { operations, environmental } \\
\text { protection and utilization; } \\
\text { Felling and bucking } \\
\text { methods to prioritise worker } \\
\text { safety, ensure efficiency, } \\
\text { and minimize logging waste } \\
\text { Efficient and low } \\
\text { environmental impact } \\
\text { skidding with planning and } \\
\text { operational controls down } \\
\text { to the individual tree level } \\
\text { Deactivation activities } \\
\text { (e.g.post-logging road and } \\
\text { skid trail closure) to reduce } \\
\text { soil erosion and restrict } \\
\text { illegal access } \\
\text { Construct and maintain } \\
\text { logging roads so as to } \\
\text { minimize soil erosion and } \\
\text { facilitate log transport } \\
\text { Monitor compliance with } \\
\text { RIL guidelines and ensure } \\
\text { company-wide utilization } \\
\text { RIL training and } \\
\text { supervision }\end{array}$ & $\begin{array}{l}\text { Similar to FSC } \\
\text { requirements, RIL is a } \\
\text { must in PEFC, which } \\
\text { includes requirements on } \\
\text { tree felling, bucking and } \\
\text { log yarding as well as on } \\
\text { soil and water protection } \\
\text { functions }\end{array}$ \\
\hline
\end{tabular}


Table 2 (continued)

\begin{tabular}{|c|c|c|c|}
\hline $\begin{array}{l}\text { Forest management } \\
\text { components }\end{array}$ & Government regulations & FSC requirements & PEFC requirements \\
\hline $\begin{array}{l}\text { Environmental management } \\
\text { and monitoring plan }\end{array}$ & $\begin{array}{l}\text { Prepare environmental } \\
\text { management and } \\
\text { monitoring plans (Analisis } \\
\text { Dampak } \\
\text { Lingkungan-AMDAL) for } \\
\text { reduction and monitoring } \\
\text { of soil erosion, protection } \\
\text { of flora and fauna, and } \\
\text { community development } \\
\text { programs; } \\
\text { Prepare annual reports on } \\
\text { plan implementation }\end{array}$ & $\begin{array}{l}\text { Integration of monitoring } \\
\text { protocols and results into } \\
\text { forest management plans as } \\
\text { well as making public the } \\
\text { results of these monitoring } \\
\text { activities; } \\
\text { Infrastructure changes } \\
\text { generally required for fuel } \\
\text { handling, recycling and } \\
\text { general waste management }\end{array}$ & $\begin{array}{l}\text { Requiring the } \\
\text { documentation of } \\
\text { measures regarding land } \\
\text { use, forest protection } \\
\text { functions, and forest fire } \\
\text { prevention, amongst } \\
\text { others. In contrast to FSC, } \\
\text { PEFC also requires an } \\
\text { R\&D plan. However, } \\
\text { PEFC does not mention } \\
\text { detailed requirements }\end{array}$ \\
\hline Biodiversity conservation & $\begin{array}{l}\text { No explicit regulations } \\
\text { require biodiversity } \\
\text { conservation at the } \\
\text { concession level. Small } \\
\text { portions of concessions } \\
\text { should be set aside to } \\
\text { protect genetic resources }\end{array}$ & $\begin{array}{l}\text { Extensive training and } \\
\text { substantial investments in } \\
\text { external consultants are } \\
\text { required for HCVF surveys } \\
\text { and development of } \\
\text { biodiversity management } \\
\text { plans; } \\
\text { Other required } \\
\text { HCVF-related activities } \\
\text { include stakeholder } \\
\text { consultations and } \\
\text { incorporation of habitat } \\
\text { protection and monitoring } \\
\text { of planning and operational } \\
\text { procedures }\end{array}$ & $\begin{array}{l}\text { Identify, maintain and } \\
\text { repair the habitat of } \\
\text { protected flora and fauna, } \\
\text { endemic, rare and } \\
\text { threatened/endangered } \\
\text { species and features of } \\
\text { special biological interests } \\
\text { in accordance with the } \\
\text { regulations/conventions; } \\
\text { Identify key protected and } \\
\text { endangered fauna species, } \\
\text { their habitats and } \\
\text { migration patterns, } \\
\text { including landscape } \\
\text { consideration; and apply } \\
\text { appropriate management } \\
\text { measures to minimize the } \\
\text { pressure of forest } \\
\text { operations on those } \\
\text { species as well as to } \\
\text { minimize potential } \\
\text { negative impacts of those } \\
\text { species on local } \\
\text { communities; } \\
\text { Carry out environmental } \\
\text { impact assessment of the } \\
\text { potential impacts on } \\
\text { protected flora and fauna, } \\
\text { endemic, rare and } \\
\text { threatened/endangered } \\
\text { species; and incorporate } \\
\text { measures to mitigate those } \\
\text { impacts and } \\
\text { disruptions;The protected } \\
\text { and endangered flora and } \\
\text { fauna species shall not be } \\
\text { exploited for commercial } \\
\text { purposes }\end{array}$ \\
\hline
\end{tabular}


Table 2 (continued)

\begin{tabular}{|c|c|c|c|}
\hline $\begin{array}{l}\text { Forest management } \\
\text { components }\end{array}$ & Government regulations & FSC requirements & PEFC requirements \\
\hline $\begin{array}{l}\text { Social impact assessment } \\
\text { and community } \\
\text { development programs }\end{array}$ & $\begin{array}{l}\text { Concessions are required } \\
\text { to develop social programs } \\
\text { for local people (MOEF } \\
\text { Decree691/Kpts-II/1991) }\end{array}$ & $\begin{array}{l}\text { Social baseline surveys and } \\
\text { social impact assessments; } \\
\text { Help with community } \\
\text { development programs } \\
\text { using participatory } \\
\text { processes; } \\
\text { Monitor social impacts and } \\
\text { evaluate programme } \\
\text { effectiveness; } \\
\text { Resolve land tenure and } \\
\text { other rights issues on a } \\
\text { case-by-case basis using } \\
\text { procedures developed by } \\
\text { the concession; } \\
\text { All activities that affect } \\
\text { communities need to be } \\
\text { preceded by community } \\
\text { consultations with broad } \\
\text { stakeholder participation }\end{array}$ & $\begin{array}{l}\text { Identify, honour, } \\
\text { recognize and respect } \\
\text { customary rights of the } \\
\text { indigenous peoples in } \\
\text { compliance with the } \\
\text { national legislation and } \\
\text { taking into account ILO } \\
\text { Convention } 169 \text { and the } \\
\text { UN Declaration on the } \\
\text { Rights of Indigenous } \\
\text { Peoples of 2007; } \\
\text { Ensure that forest } \\
\text { management does not } \\
\text { threaten or diminish, } \\
\text { either directly or } \\
\text { indirectly, the resources or } \\
\text { tenure rights of indigenous } \\
\text { peoples and minimize any } \\
\text { negative impact; } \\
\text { Establish a participatory } \\
\text { and equitable agreement } \\
\text { to manage the forest area } \\
\text { based on customary } \\
\text { and/or legal rights of the } \\
\text { communities; } \\
\text { Establish a conflict } \\
\text { resolution mechanism, } \\
\text { which shall be designed in } \\
\text { a participatory manner, } \\
\text { and mutually accepted and } \\
\text { agreed; } \\
\text { Carry out a social impact } \\
\text { assessment of forest } \\
\text { management activities }\end{array}$ \\
\hline $\begin{array}{l}\text { Worker rights, health and } \\
\text { safety }\end{array}$ & $\begin{array}{l}\text { Concessions should follow } \\
\text { the labour law (Law } \\
\text { 13/2003) and related } \\
\text { regulations }\end{array}$ & $\begin{array}{l}\text { Comply with all national } \\
\text { regulations and } \\
\text { international conventions } \\
\text { related to workers; } \\
\text { Proper safety equipment } \\
\text { provided and utilized; } \\
\text { Adequate training and } \\
\text { supervision provided and } \\
\text { documented }\end{array}$ & $\begin{array}{l}\text { Comply with all national } \\
\text { regulations and } \\
\text { international conventions } \\
\text { related to normative rights } \\
\text { of the workers; } \\
\text { Give workers access to } \\
\text { support for their collective } \\
\text { bargaining; } \\
\text { Provide workers with } \\
\text { adequate facilities and } \\
\text { infrastructure; } \\
\text { To have systems to detect } \\
\text { and avoid/respond to } \\
\text { potential threats to the } \\
\text { health and safety of } \\
\text { workers and their } \\
\text { workplace environment }\end{array}$ \\
\hline
\end{tabular}


Table 2 (continued)

\begin{tabular}{l|l|l|l}
\hline $\begin{array}{l}\text { Forest management } \\
\text { components }\end{array}$ & Government regulations & FSC requirements & PEFC requirements \\
\hline $\begin{array}{l}\text { Yield sustainability and } \\
\text { silviculture }\end{array}$ & $\begin{array}{l}\text { Comply with TPTI (MoF } \\
\text { Decree 485/Kpts/II/ } \\
1989 \text { and MoFDecree } \\
\text { P.11/Menhut- II/2009) }\end{array}$ & $\begin{array}{l}\text { Intensive growth and yield } \\
\text { monitoring are required; } \\
\text { Harvest levels should be } \\
\text { revised based on } \\
\text { monitoring results; } \\
\text { Logging intensities should } \\
\text { be reduced, and logging } \\
\text { cycles lengthened }\end{array}$ & $\begin{array}{l}\text { PEFC requires merely } \\
\text { general things about yield } \\
\text { sustainability and } \\
\text { silviculture. It only } \\
\text { mentions that the } \\
\text { management plan has to } \\
\text { include silviculture } \\
\text { technique and that the } \\
\text { harvest rate must not } \\
\text { exceed the rate of } \\
\text { sustainable production }\end{array}$ \\
\hline
\end{tabular}

Source Columns 1, 2, and 3 from Ruslandi et al. (2014); Column 4 authors' elaboration

level of government regulations on RIL is low (Ruslandi et al., 2014), PEFC and FSC requirements on RIL strengthen government regulation.

Regarding their environmental management and monitoring plan, $\mathrm{PEFC}$ requires concessions to provide documentation of measures relating to land use, forest protection functions and forest fire prevention. It also requires an R\&D plan. In this regard, the PEFC requirement is in line with those of the government and FSC. However, the FSC requirement is more detailed than that of PEFC. For instance, FSC lists examples of particular activities that have to be mentioned in the evaluation report if those activities are to be conducted by concessions in future. FSC also requires concessions to include particular measures such as water flow management in their plan.

Biodiversity conservation and protection: Compared to governmental regulations and FSC, the PEFC scheme has set at least two important emphases: (1) the importance of not only maintaining the (key) protected flora and fauna, endemic, rare and threatened/endangered species and their habitats in accordance with the national regulations and international conventions but also repairing their habitat and features of special biological interests and (2) the obligation to carry out the environmental impact assessment (EIA) indicated in point (1) and to incorporate measures to mitigate those impacts and disruptions.

In the framework of forest management components, the PEFC requirements reinforce the existing ones and provide more comprehensive parameters compared to government regulations, i.e. the mandatory PHPL, and also compared to the existing voluntary certification scheme, the FSC. For the government, this is quite important because there are no explicit regulations that require biodiversity protection and conservation at the concession unit level, nor in the framework of the national legislation agenda to amend the specific law concerning biodiversity (Act No. 5/1990) (Prolegnas, 2015; Ruslandi et al., 2014).

Social impacts and community development: Compared to the mandatory PHPL and the FSC, the PEFC provides more detailed parameters on the fulfilment of certification requirements regarding the customary and legal rights of indigenous people. 
Several specific aspects of the PEFC scheme can be summarized as follows: (1) the strengthening of the credibility of conflict resolution within the framework of forest management, which is closely related to the customary and legal rights of the indigenous people/community, through a participatory and equitable agreement and institutionalized mechanism; (2) the ambitious obligation to carry out a social impact assessment of forest management activities regarding indigenous people and/or local communities, prior to their implementation; and (3) the obligation for the holder of the forest concession to identify the forest resources that have important value for recreation purposes and to protect them from the negative impacts of recreation activities. This parameter is thus strengthening governmental regulations, which were seen to have failed to enforce community development programmes as an obligation for forest concession holders (Ruslandi et al., 2014).

Workers' normative rights: Both the FSC and the PEFC set more or less comparable requirements regarding the obligation of the forest concession holders to fulfil all related normative rights of workers employed in these sectors in compliance with national regulations and international conventions, both in their operations and workplace infrastructure. However, compared to the FSC scheme, PEFC requirements seem to be slightly more imperative in this case in terms of the workers' rights to collective bargaining with their company. In this regard, the PEFC clearly both complements and strengthens the governmental regulations.

Yield sustainability and silviculture: PEFC requirements are very general, only requiring that silviculture techniques be included in the management plan, and that the harvest rate of forest products not exceed the rate of sustainable production. FSC, in turn, requires regular monitoring of harvest rates and logging cycles as well as their revision if the rates are not appropriate.

In general, PEFC requirements in Indonesia are not as detailed as those of FSC. For example, the FSC document exemplifies significant activities that have to be included in the EIA that a company has to undertake. Meanwhile, PEFC details only the list of prohibited ingredients for pesticides. Another notable difference is that PEFC mentions several times that it requires concessions to be in compliance with national legislation including SVLK. This means that PEFC does not want to be contradictory to government regulations, and perhaps wants to gain the government's endorsement. This also indicates that PEFC does not substitute government regulations.

Having analysed the FSC and PEFC columns in the table above, it seems that PEFC does not add important requirements for SFM. Both FSC and PEFC show many similarities for each forest management component. Therefore, even though FSC and PEFC may not complement each other, both of them complement government regulations. 


\section{Discussion}

\subsection{PEFC Acceptability}

This section makes an attempt to predict whether PEFC will be widely acceptable in the forest industry in Indonesia. The acceptability depends on PEFC's current status in the country, the nature of its criteria, its differences compared to the existing scheme, i.e. FSC, and the socio-political conditions in the country.

To begin with, it is worth noting that both FSC and PEFC are similar certification systems which focus on source-oriented standards in an effort to achieve SFM and sustainably produced wood. They have the same primary goal, which is to maintain and sustain the ecosystem integrity and its social functions (Van Bueren, 2010) (Table 3). Their mission is, quite simply, sustainable tropical forest management. Therefore, as forest policy analysts say, their proposed solution is developing a set of global sustainable forestry principles and criteria, engaging national and sub-national multistakeholder committees to develop regionally appropriate standards, inviting third parties to audit forestry operations for compliance, and finally, certifying those who pass the test (Cashore, Gale, Errol, \& Newsom, 2006). However, they are in fact competing agents, and even prominent competitors of one another (Bernstein \& Cashore, 2003; Cashore, Gale, Errol, \& Newsom, 2006). The FSC, in its operations worldwide, still has to find some accommodation with its competitors (Bernstein \& Cashore, 2003).

Normatively, the standards of the PEFC system are adaptable to the national characteristics, involving multiple stakeholders for consensus-based certifications. This system is also developed in a framework of cooperative action and without any negative campaign against any forest management unit. In this regard, the market sees it as a system which is easily accessible. The government itself sees that both the voluntary and mandatory certification systems have different histories, mechanisms and goals, but these schemes continue to have similar frameworks for developing

Table 3 Certification systems relevant to forest management

\begin{tabular}{l|l|l}
\hline \multicolumn{2}{l|}{ Source-oriented standards } & Goal \\
\hline $\begin{array}{l}\text { SFM/sustainably produced } \\
\text { wood }\end{array}$ & FSC & $\begin{array}{l}\text { Maintain and sustain the } \\
\text { ecosystem integrity and its } \\
\text { social functions }\end{array}$ \\
\cline { 2 - 2 } & $\begin{array}{l}\text { PEFC international and national } \\
\text { systems endorsed by PEFC }\end{array}$ & $\begin{array}{l}\text { ISO environment management } \\
\text { system }\end{array}$ \\
\cline { 2 - 3 } & $\begin{array}{l}\text { RIL standard, Tropical Forest } \\
\text { Foundation (USA) }\end{array}$ & \\
\hline
\end{tabular}

Source Van Bueren (2010) 
Table 4 Comparing voluntary certification schemes and their operations

\begin{tabular}{l|l|l}
\hline Dimension & PEFC & FSC \\
\hline Year of launching & 1999 & 1994 \\
\hline $\begin{array}{l}\text { Year of introduction in } \\
\text { Indonesia }\end{array}$ & 2014 & 2000 \\
\hline Area coverage worldwide & 304 million hectares & 199 million hectares \\
\hline Area coverage in Indonesia & 3.8 million hectares & 3.1 million hectares \\
\hline Number of certificates & 60 & 39 \\
\hline Perception & Forest production industry & Environmental activists \\
\hline Criteria & $\begin{array}{l}\text { Countries create their own } \\
\text { standards based on seven } \\
\text { meta-standards }\end{array}$ & $\begin{array}{l}\text { Ten rigid principles and } \\
\text { criteria, to be applied } \\
\text { universally }\end{array}$ \\
\hline
\end{tabular}

Sources Buckingham and Jepson (2013); Authors' respondent; FSC (2018); PEFC (2017); IFCC (2018)

criteria and indicators aimed to infuse sustainability principles into forest production and management. Thus, their development and implementation are likely to be mutually reinforcing and synergetic (MOEF, s.a.).

As a market-driven certification scheme, the PEFC system has received relatively positive responses from concession holders. Forest coverage by this certification system has now grown to 304 million hectares worldwide (PEFC, 2017). Meanwhile, the FSC scheme, which was introduced much earlier in 1994, covers only 199 million hectares (FSC, 2018) (Table 4). This suggests that the certification system developed by the PEFC may have wider market acceptability.

In Indonesia, the PEFC certification system was introduced by the Indonesian Forestry Certification Cooperation (IFCC) as its National Governing Body at the end of 2014. Although it is still new and in the development phase, the PEFC scheme has had relatively high acceptability in Indonesia too. Within less than a year following its introduction, for instance, more than 600,000 ha (PEFC, 2015) of the industrial forest plantation (HTI-Hutan Tanaman Industri) were certified, a number that reached 3.7 million hectares in early 2018 (IFCC, 2018). At the same point in time, the FSC scheme, which had been introduced in 2000 already, covered Indonesian forest area of 3.1 million hectares (FSC, 2018) (Table 4). This assessment confirms earlier studies suggesting that the attraction to FSC certification remains comparatively weak in developing countries (Bernstein \& Cashore, 2003; Cashore, Gale, Errol, \& Newsom, 2006). Current data shows that only 23\% of FSC-certified forest area is located in developing countries. Under the PEFC scheme, in fact, the share of developing countries in global certified area is even less - at around 9\%. Nonetheless, the significance of these numbers should not be exaggerated. Principles introduced within the FSC scheme are universally applied to all countries, while principles under the PEFC scheme are prepared by the respective country and then agreed upon. In this regard, both schemes are rolled out according to their respective characteristics. The FSC scheme is perceived to be designed by environmentalists, whereas the 
PEFC is seen to be closer to the interests of forest production industries by analysts such as Buckingham and Jepson (2013). We can easily understand why some studies conclude that getting FSC certification will be time consuming and costly (Bartley 2010; Ruslandi et al., 2014). Requirements and standards imposed by the PEFC are not as tight as those imposed by the FSC. For instance, FSC certification cannot be granted to HTI which was converted from natural forest after November 1994, whereas PEFC certification only lexcludes plantation forest which was converted from natural forest after 2010. It is, therefore, the big groups of forest concession holders in Indonesia like the Asia Pulp and Paper (APP) and Asia Pacific Resources International Limited (APRIL Group) that have obtained PEFC certification.

Since the PEFC scheme seems relatively acceptable to the market in terms of its principles and standards, which are nationally adaptable and involve multiple stakeholders, more HTI areas may become PEFC-certified in future. An Indonesian forest business association, for instance, argued that the PEFC system, which is voluntary and market-driven, can be an important instrument to realize SFM as the system is also primarily targeted to achieve economic, social and ecological sustainability. The importance of this ISO-based scheme can also be seen as having strategic value for the market survival of forest concession holders. Indeed, rising concerns of forest companies to join PEFC may hint to its positive economic impact. The voluntary scheme can also strengthen the SFM processes which are normatively imposed by the state institution in charge, namely the MOEF in the context of enforcing the regulation, facilitation and oversight of forest companies' compliance to SFM principles (interview with a business association).

However, forest concession holders in Indonesia continue to face constraints in getting voluntary forest certification-not only because of their different financial capacities to bear the certification costs but also because of different preparation levels (Brockhaus, Obidzinski, Dermawan, Laumonier, \& Luttrell, 2012). Companies who got certified have usually applied SFM practices right from the beginning so that they do not have to bear huge certification costs (interview with a forestry researcher).

\subsection{The PEFC Scheme's Implications for SFM in Indonesia}

As indicated above, PEFC may strengthen the SFM policies that Indonesia has so far undertaken for social and environmental protection including the reduction of carbon emissions from the forest sector. Even though it is comparatively well-accepted by the private sector, this does not mean that PEFC will automatically become the main source of certification. As mentioned before, the government itself has developed and imposed a mandatory certification scheme, PHPL, for forest concession holders. This programme was actually an improved version of a set of voluntary government programmes commissioned by LEI. It resulted from the concerns of environmental activists as well as USA and European tropical timber consumers demanding a certification programme (as a market instrument) for forest products to reduce the pace of tropical forest degradation in the world (MOEF, 2015). However, the programme 
does not address the technical problem of trade of forest timber and is not targeted to fulfil market demands in the same way as the voluntary certification programmes.

In addition, the Indonesian forest business association has planned to develop a so-called SelfDeclare certification programme. This programme is mandatory for all association members with the purpose of measuring their actual performance in achieving sustainable production forest management. It aims to promote its members' readiness to fulfil the governmental mandatory certification programme and the voluntary market-driven programmes. Since the certification programme is mainly about facilitation, the criteria and indicators used as a basis for evaluation focus on input and processes rather than on output.

Despite the existence of other initiatives, there are prospects for continued and growing acceptance of the PEFC certification scheme in Indonesia. Since the PHPL programme does not necessarily suit market demands, the PEFC scheme, based on nationally adapted principles and standards, may become a viable voluntary alternative.

Indeed, PHPL faces a number of constraints relating to implementing agencies' capacities and poor performance of forestry governance and certain law enforcement activities. The introduction of the FSC and PEFC certification programmes was in part driven by a lack of "market trust". This lack of trust, which had also resulted in the imposition of a due diligence policy for Indonesian forest products earlier on, relates to high corruption levels in Indonesia as well as poor forest management indices (interview with a certification body), amongst other issues. PHPL's performance also depends on the degree to which government-to-government (Gto-G) SFM cooperation mechanisms between Indonesia and the countries of timber product consumers are strengthened. If this is not the case, the credibility of the PHPL scheme as an instrument to achieve SFM may suffer. There is also a growing concern amongst producers that consumers from other major markets outside the USA and Europe are likely to demand tighter certification of forest products as well. In this regard, forest producers have begun to realize that a market-driven voluntary certification scheme such as PEFC is a choice they have to make (interview with a business association).

Overall, the future application and success of the PEFC scheme in Indonesia will be dependent on two significant aspects. First, a high level of support from the main stakeholders, namely civil society, industry and, most importantly, the government, will be required. As in the regional context, voluntary certification programmes in Indonesia have in fact not been getting full support from these main stakeholders. Data shows that the Indonesian government was not supportive enough of some voluntary forest certification schemes, in this case the FSC, while voluntary standards developed by LEI were seen as an important way to preserve national autonomy and sovereignty as well as compatibility with domestic circumstances. In the context of Indonesian industry, the development of LEI standards was at least in part supported by the industry associations. With regard to civil society support, the Rainforest Alliance has played an active role, with its SmartWood programme certifying the first-ever developing country forest operation, Perum Perhutani, in 
Indonesia in 1990. But, there are also NGOs that have not been supportive of voluntary certification. The World Rainforest Movement, allied with local forestry NGOs such as the Indonesian Forum for the Environment (WALHI-Wahana Lingkungan Hidup Indonesia), for instance, called for a moratorium on FSC and LEI certification. This socio-economic and political constellation underlines a viable argument that the Asia-Pacific region basically lacks the general structural conditions for effective forest certification (Cashore, Gale, Errol, \& Newsom, 2006).

Second, the legitimacy of PEFC will flow from both domestic and global actors. The importance of the legitimacy issue here can be seen in the context of PEFC's status as a non-state (governance) scheme, which means that it lacks the traditional enforcement capacities associated with the sovereign state in the realm of global governance (Howlett \& Ramesh, 1995; Bernstein \& Cashore, 2003). Even though voluntary forest certification plays an important role in the absence of binding international law on tropical forest use, its global legitimacy is still contested and this has local repercussions. In terms of domestic legitimacy, stakeholders' hesitant acceptance of FSC is an experience that PEFC should keep in mind. The degree to which the scheme becomes an effective anchor for national SFM in Indonesia and also for the governance of global emissions from the forestry sector remains to be seen.

\section{Conclusion}

This study investigated whether PEFC as a relatively new forest certification system in Indonesia substitutes or complements the existing forest certification systems, which mainly are FSC and government regulations. In addition, this study also aimed to predict whether concession holders are likely to be further attracted to obtain PEFC certification. In other words, the study sought to understand the role PEFC is likely to play for the purpose of SFM in Indonesia.

This study found that PEFC seems to substitute FSC as both schemes are very similar but FSC requirements are more detailed and stricter than PEFC's and thus attract fewer concession holders. Both PEFC and FSC complement government regulations as both voluntary schemes require higher standards than the government regulations. This indicates that voluntary forest certification schemes can play a role to fill the global forest governance gap in the absence of a binding hard law.

However, to measure PEFC acceptability in Indonesia, two aspects still play an importance role-the degree to which domestic stakeholder support is given, and PEFC's global legitimacy as a non-state scheme. Some of the domestic stakeholders including the government and parts of civil society do not show sufficient support. Thus, its potential contribution to national SFM in Indonesia and, eventually, to the governance of global emissions from the forestry sector remains to be seen.

Future research could delve into the technical requirements of each certification scheme and its applicability in the Indonesian forestry sector. Analysing perceptions of a broad range of stakeholders regarding each scheme is also important in order to determine best practices for forest management. 


\section{References}

Bartley, T. (2010). Transnational private regulation in practice: The limits of forest and labor standards certification in Indonesia. Business and Politics., 12(3), 1-36.

Bernstein, S., \& Cashore, B. (2003). Nonstate global governance : Is forest certification a legitimate alternative to a global forest convention? In J. Kirton \& M. Trebilcock (Eds.), Hard choices, soft law: Voluntary standards in global trade, environment and social cohesion in global governance (pp. 33-64). Ashgate Press.

Brockhaus, M., Obidzinski, K., Dermawan, A., Laumonier, Y., \& Luttrell, C. (2012). An overview of forest and land allocation policies in Indonesia: Is the current framework sufficient to meet the needs of REDD+? Forest Policy and Economics, 18, 30-37. https://doi.org/10.1016/j.forpol. 2011.09.004.

Buckingham, K., \& Jepson, P. (2013). Forest certification with Chinese characteristics: State engagement with non-state market-driven governance. Eurasian Geography and Economics, 54(3), 280-299.

Cashore, B., Gale, F., Errol, M., \& Newsom, D. (2006). Forest certification in developing and transitioning countries. Environment, 48(9).

Contreras, A., \& Fay, C. (2005). Strengthening forest management in Indonesia through land tenure reform: Issues and framework for action, Forest Trends.

Djama, M. (2011). Articulating private voluntary standards and public regulations. Paris: CIRAD.

FSC. (2018). FSC facts \& figures. Retrieved from https://ic.fsc.org/file-download.facts-figures-jan uary-2018.a-3327.pdf.

Hagen, O. v., \& Alvarez, G. (2011). The interplay of public and private standards. Geneva: International Trade Centre.

Howlett, M., \& Ramesh, M. (1995). Studying public policy: Policy cycles and policy subsystems. Oxford: Oxford University Press.

IFCC. (2018). IFCC sustainable forest management certificate holder. Retrieved from http://www. ifcc-ksk.org/index.php/2015-02-17-06-11-24/2015-02-17-06-12-36.

International Trade Center. (2012). Market access, transparency and fairness in global trade. Switzerland: ITC Press.

Maryudi, A. (2015). The political economy of forest land-use, the timber sector, and forest certification. In C. Romero, F. E. Putz, M. R. Guariguata, E.O. Sills, A. Maryudi \& Ruslandi (Eds.), The context of natural forest management and FSC Certification in Indonesia (Occasional Paper 126). Bogor, Indonesia: Cifor.

Ministry of Forestry. (2014). Statistik Kementerian Kehutanan 2013. Jakarta: Ministry of Forestry.

Ministry of Forestry. (2015). Ministry of forestry, Republic of Indonesia. Retrieved November 19, 2015, from Kementerian Kehutanan: http://www.dephut.go.id/Halaman/standardisasi_\&_lingku ngan_kehutanan/info_V02/I_V02.htm.

MOEF. (2016). What and how SVLK. Retrieved from http://silk.dephut.go.id/index.php/info/vsv $1 \mathrm{k} / 3$.

MOEF. (2018). Statistik Lingkungan Hidup dan Kehutanan Tahun 2017. Jakarta: Ministry of Environment and Forestry.

Muhtaman, D. R., \& Prasetyo, F. A. (2006). Forest certification in Indonesia. In B. Cashore, F. Gale, E. Meidinger, \& D. Newsom, (Eds.), Confronting sustainability: Forest certification in transitioning and developing countries. Yale School of Forestry and Environmental Study Report no 8.

Nurtjahjawilasa, D. K., Yasman, I., Septiani, Y., \& Lasmini. (2013). Konsep dan kebijakan pengelolaan hutan produksi lestari dan implementasinya (Sustainable forest management/SFM). Jakarta: Program Terestrial the Nature Conservancy Indonesia.

PEFC. (2015). Indonesia celebrates its first PEFC-certified forests. Retrieved from https://www. pefc.org/news-a-media/general-sfm-news/1873-indonesia-celebrates-its-first-pefc-certified-for ests. 
PEFC. (2017). PEFC global statistics-SFM \& CoC certification. Retrieved from https://www. pefc.org/images/documents/PEFC_Global_Certificates_-_Sep_2017.pdf.

Prolegnas. (2015 November, 27). Dewan Perwakilan Rakyat (House of representatives). Retrieved from Indonesia: http://www.dpr.go.id/uu/prolegnas-long-list.

Romero, C., Putz, F., Guariguata, Sills, E. O., Maryudi, A., \& Ruslandi. (2015). The context of natural forest management and FSC certification in Indonesia. Bogor: CIFOR.

Ruslandi., Klassen, A., Romero, C., \& Putz, F. (2014 June, 1). Forests under pressure-Local responses to global issues, 32, 255-272.

UNFCCC. (2016). First nationally determined contribution, Republic of Indonesia. Retrieved fromhttps://www.google.com/search?client=firefox-b-d\&q=Indonesian+NDC+UNFCCC.

Van Bueren, E. L. (2010). Forest-related standards and certification schemes. ETFRN News 51, 11-19. Retrieved from www.etfrn.org/file.php/128/1.2lammerts-van-bueren.pdf.

Open Access This chapter is licensed under the terms of the Creative Commons Attribution 4.0 International License (http://creativecommons.org/licenses/by/4.0/), which permits use, sharing, adaptation, distribution and reproduction in any medium or format, as long as you give appropriate credit to the original author(s) and the source, provide a link to the Creative Commons license and indicate if changes were made.

The images or other third party material in this chapter are included in the chapter's Creative Commons license, unless indicated otherwise in a credit line to the material. If material is not included in the chapter's Creative Commons license and your intended use is not permitted by statutory regulation or exceeds the permitted use, you will need to obtain permission directly from the copyright holder.

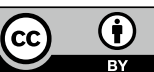

